\title{
Correction to: Invited Discussion on: Muscle-Splitting Transaxillary Breast Implant Revision Surgery: a Single Surgeon's Experience
}

\author{
Maria Cecilia Closs Ono ${ }^{1} \cdot$ Ruth $_{\text {Graf }}{ }^{1}$ (D)
}

Published online: 16 April 2021

(C) Springer Science+Business Media, LLC, part of Springer Nature and International Society of Aesthetic Plastic Surgery 2021

\section{Correction to: Aesth Plast Surg}

https://doi.org/10.1007/s00266-021-02210-w

This article was updated to correct reference 3 .
Publisher's Note Springer Nature remains neutral with regard to jurisdictional claims in published maps and institutional affiliations.

The original article can be found online at https://doi.org/10.1007/ s00266-021-02210-w.

\footnotetext{
Ruth Graf

ruthgraf@uol.com.br

1 Department of Surgery, Universidade Federal do Paraná,

Curitiba, Paraná, Brazil
} 